\title{
Effect of including different levels of palm kernel cake to dairy cow concentrate on milk production and composition
}

\author{
S.G. Jin', M. Li ${ }^{1,3}$, W. Liu' ${ }^{2}$ and Y. Zhou ${ }^{1}$ \\ ${ }^{1}$ College of Animal Science and Medical Science, Inner Mongolia Agricultural University \\ Huhhot 010018, P.R. China \\ ${ }^{2}$ Tianjin Chiatai Feed Tech. CO., P.R. China
}

\begin{abstract}
A study was conducted to determine effects of including different content of palm kernel cake (PKC) to milk cow concentrate on milk production of 24 Australian-Holstein dairy cows. Twenty four midlactation cows were randomly divided into four groups (three experimental and one control) of 6 cows each. During trial periods, the PKC content of three experimental groups were 10, 15 and 18\%, and control group were fed concentrates without including PKC. Over 30 days study, the milk protein contents in I and II experimental groups and milk yields in I, II and III experimental groups were significantly $(\mathrm{P}<0.05)$ higher than those of control. There were no significantly $(\mathrm{P}>0.05)$ difference between experimental and control groups in milk fat, total milk dry matter and lactose improvement. Comparing experimental groups with control, including PKC in dairy cow concentrate had positively effect on milk quality improvement, and milk production capacity was slightly increased.
\end{abstract}

KEY WORDS: palm kernel cake, milk production, cows

\section{INTRODUCTION}

Palm kernel cake (PKC), due to its availability and low cost, is one potential feed ingredient for satisfying the enlargement of livestock and feed production in China. PKC is the palm oil milling by-product, which is the solid residue left behind after the extraction of oil from the kernels of the palm fruits. PKC by itself is a medium grade protein feed and with its high fibre content it is often consider as suitable for feeding of ruminants. The feasibility and practicability

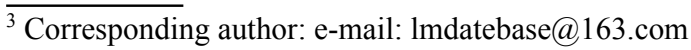


of commercial feedlot using PKC as the sole feed has been reported (Mustaffa, 1987). By including PKC in cattle concentrates, it has been found that the beef characteristics of Droughtmaster cattle perform better than that of local Indian dairy crossbreds and the Sahiwal-Friesian animals (Yusoff et al., 1987). Their respective daily gains were $0.85,0.63$ and $0.65 \mathrm{~kg}$. The average daily gain of the Australian Commercial Cross (ACC), another beef breed, fed with PKC was found to be very promising at about $0.84 \mathrm{~kg}$, with a feed conversion ratio of 6.96 (Hutagalung et al., 1986). Because PKC is not yet widely used in China feed market, the objective of current research was to determine the effect of using palm kernel in dairy cow concentrates on the milk production and composition. The optimum ratio of PKC used in cow concentrates was found based on the view of quality and quantities of milk production and related economic benefit.

\section{MATERIAL AND METHODS}

\section{Materials}

Experiment was carried out in Cattle Feedlot of Inner Mongolia XuRi Biology Technique Company. Feed manufacturing equipments included hammer mill and mixer. Feed ingredients of cow concentrates included PKC, maize meal, wheat bran, soyabean meal, barley, premix, salt and limestone.

\section{Methods}

Twenty-four Australian-Holstein dairy cows were used. The recorded average body weight before the trial was $550 \pm 10 \mathrm{~kg}$ and the age was around two and half years. The cows were randomly divided into four groups (three experimental and one control) and each group included 6 animals. During trial periods, cattle of three control groups were fed concentrates including 10,15 or $18 \%$ PKC. Cattle of control group were fed concentrate without PKC. The composition of cow concentrates was showed in Table 1.

Each cattle was manual fed concentrate three times per day and drinking water was available. Milking were three times every day and the milk yields were recorded. The periods of pre-experiment were 15 days and the periods of experiment were 30 days. The samples of mixed milk were analysed weekly by using Denmark FOSS Company FT120 in MengNiu Milk Production Company and the main analysed components included milk fat content, milk protein, lactose, total milk solids and total fat-free solids. 


\section{Statistical analysis}

Data were analysed by using statistical software SAS (SAS Institute, 1997). Differences among treatments were by the least significant difference at $\mathrm{P}<0.05$.

Table 1. Composition and nutritive value of of concentrates

\begin{tabular}{lcccc}
\hline \multirow{2}{*}{ Item } & \multirow{2}{*}{ Control \% } & \multicolumn{3}{c}{ Group } \\
\cline { 3 - 5 } & & I & II & III \\
\hline Composition, \% & 50 & 51 & 51 & 51 \\
maize meal & 18 & 17 & 17 & 17 \\
lineseed meal & 17 & 7 & 2 & 0 \\
wheat bran & 8 & 8 & 7 & 7 \\
cottonseed cake & 3 & 3 & 4 & 3 \\
soyabean meal & 3 & 3 & 3 & 3 \\
Premix & 1 & 1 & 1 & 1 \\
salt & 0 & 10 & 15 & 18 \\
PKC & & & & \\
Nutritive value & 1.44 & 1.68 & 1.68 & 1.67 \\
ME, MJ/Kg & 18.04 & 16.73 & 16.73 & 3.79 \\
crude protein, \% & 2.65 & 3.11 & 3.35 & 0.19 \\
crude fat, \% & 0.16 & 0.17 & 0.18 & 0.49 \\
Ca, \% & 0.52 & 0.51 & 0.49 & \\
P, \% & & & & \\
\hline
\end{tabular}

${ }^{1}$ analysis of palm kernel cake (as-fed basis), \%: dry matter 93.70, crude protein 20.1, ether extract 7.8, ash 4.85, crude fibre 19.20, N-free extractives 35.75 (all analysed by Animal Nutrition Laboratory, College of Animal Science and Animal Medicine, Inner Mongolia Agricultural University)

\section{RESULTS}

As shown in Table 2, the milk yield of experimental groups (I, II, III) was significantly higher than that of control group, and there were no significantly difference $(\mathrm{P}>0.05)$ of milk yield between experimental groups. Milk protein content of experimental groups (I, II) was significantly higher than that of control group, and experimental group I had the highest milk protein content. Milk fat, lactose and total milk solids of experimental groups did not differ $(\mathrm{P}>0.05)$ comparing with control group.

As shown in Table 3, comparing with control and experimental groups, the cost of concentrate exhibited decreasing tendency. The highest cost of concentrate was present in control group, which was 1551.9 Yuan per ton; the lowest cost of concentrate was present in experimental group III, which was 1442.2 Yuan per ton. 
Table 2. Effect of including different level of PKC to cow concentrates on milk production and composition

\begin{tabular}{lcccc}
\hline \multirow{2}{*}{ Item } & \multirow{2}{*}{ Control } & \multicolumn{3}{c}{ Group } \\
\cline { 3 - 5 } & & \multicolumn{1}{c}{ I } & II & III \\
\hline Milk yield, kg & $13.8^{\mathrm{a}} \pm 0.7$ & $15.3^{\mathrm{ab}} \pm 1.1$ & $16.5^{\mathrm{ab}} \pm 0.8$ & $19.5^{\mathrm{b}} \pm 1.0$ \\
Milk fat, \% & $4.04^{\mathrm{a}} \pm 0.34$ & $4.15^{\mathrm{a}} \pm 0.73$ & $4.13^{\mathrm{a}} \pm 0.61$ & $4.12^{\mathrm{a}} \pm 0.48$ \\
Milk protein, \% & $3.14^{\mathrm{a}} \pm 0.05$ & $3.49^{\mathrm{c}} \pm 0.18$ & $3.30^{\mathrm{b}} \pm 0.06$ & $3.26^{\mathrm{a}} \pm 0.06$ \\
Lactose, \% & $4.46^{\mathrm{a}} \pm 0.06$ & $4.60^{\mathrm{a}} \pm 0.09$ & $4.67^{\mathrm{a}} \pm 0.13$ & $4.69^{\mathrm{a}} \pm 0.11$ \\
Total milk solids, \% & $12.41^{\mathrm{a}} \pm 0.40$ & $13.02^{\mathrm{a}} \pm 0.80$ & $12.85^{\mathrm{a}} \pm 0.56$ & $12.82^{\mathrm{a}} \pm 0.41$ \\
\hline
\end{tabular}

$\mathrm{a,b,c}$ are different superscript letters indicate significant difference $(\mathrm{P}<0.05)$

Table 3. The cost of concentrates of different groups (exchange rate between USD and Yuan are around 1: 8.11), Yuan/ton

\begin{tabular}{lcrrr}
\hline \multirow{2}{*}{ Item } & \multirow{2}{*}{ Control } & \multicolumn{3}{c}{ Group } \\
\cline { 3 - 5 } & & \multicolumn{1}{c}{ I } & II & III \\
\hline Maize meal & 720.0 & 734.4 & 734.4 & 734.4 \\
Linseed meal & 252.0 & 238.0 & 238.0 & 238.0 \\
Wheat bran & 246.5 & 101.5 & 29.0 & 0 \\
Cottonseed cake & 132.8 & 132.8 & 116.2 & 116.2 \\
Soyabean meal & 78.0 & 78.0 & 104.0 & 78.0 \\
Premix & 114.0 & 114.0 & 114.0 & 114.0 \\
Salt & 8.6 & 8.6 & 8.6 & 8.6 \\
PKC & 0 & 85.0 & 127.5 & 153.0 \\
Total & 1551.9 & 1492.3 & 1471.7 & 1442.2 \\
\hline
\end{tabular}

\section{DISCUSSION}

Due to PKC supplies both protein and energy, PKC by itself is a medium grade protein and energy ingredient and with its high fibre content it is often considered as suitable for feeding of ruminants. For instances, PKC was ranked a little higher than copra cake but lower than fish meal and groundnut cake especially in its protein value (Devendra, 1977). In this research, replacement of wheat bran in experimental groups by including $\mathrm{PKC}$, the milk production capacity and milk quality was not significantly affected, but resulted in decreasing the cost of milk cow concentrates.

\section{CONCLUSIONS}

Due to palm kernel cake high nutritive value and lower prices, its advent as a feeding material increasing profitability to farmers undertaking feedlot and dairy production; improving the deficiency of raw materials supplying of China feed market could be considered as a feasible strategy. 


\section{REFERENCES}

Devendra C., 1977. Utilisation of feeding stuffs from the oilpalm. In: Feedingstuffs for Livestock in S. E. Asia, pp. 116-131

Hutagalung R.I., Mahyuddin M.D., Braithwaite B.L., Vitchulata P., Dass S., 1986. Digestibility and performance of cattle fed PKC and ammoniated PPF under intensive system. In: Proceedings of $8^{\text {th }}$ Annual Conference, MSAP. Malaysia, pp. 87-91

Mustaffa A.B., 1987. Palm kernel cake as a new feed for cattle. In: Asian Livestock, Vol. XI, No. 5, FAO/APHCA Public. Bangkok (Thailand), pp. 49-50

Yusoff S.M., Zairi S.M., Mariadass A., 1987. Effects of feeding PKC on growth and blood copper level in different breeds of beef cattle. Kajian Vet. 19, 203-207 